\title{
On probiotic yeasts in food development: Saccharomyces boulardii, a trend
}

Handray Fernandes de SOUZA ${ }^{1}$, Mariana Fronja CAROSIA ${ }^{1}$, Carolina PINHEIRO ${ }^{1}$, Marina Vieira de CARVALHO ${ }^{1}$, Carlos Augusto Fernandes de OLIVEIRA ${ }^{1 *}$ (D), Eliana Setsuko KAMIMURA ${ }^{1}$

\begin{abstract}
Studies conducted in the last decades have demonstrated the probiotic effects of several yeast species. Among the probiotic yeast evaluated, Saccharomyces boulardii is the most common and widely studied species with significant probiotic properties, such as survival capacity in the acidic environment of the gastrointestinal tract and improvements in the intestinal microbiota. In recent years, new evidence indicated that the incorporation of probiotic yeasts is also a promising approach in food development, thus leading to new perspectives for a more integrated strategy for a potential application of S. boulardii in the development of innovative functional food products. In this review, an overview of recent published data on the application of probiotic yeast in foods is presented, especially on the use of $S$. boulardii as a trend to develop several functional foods, such as non-alcoholic, fermented alcoholic, vegetable, and bakery products.
\end{abstract}

Keywords: probiotics, functional foods, innovative food, food matrixes.

Practical Application: Several probiotic yeasts strains have potential to food development. Saccharomyces boulardii presents a trend to functional food production.

\section{Introduction}

Throughout history, probiotics have been understood as living microorganisms used as food supplements in adequate amounts, which provide beneficial health effects (World Health Organization, 2006), particularly on the gut microbial balance (Moslehi-Jenabian et al., 2010). The concept of probiotics was introduced in the early 20th century by the russian scientist Elie Metchnikoff (Metchnikoff, 1907), relating the promotion of longevity and health benefits caused by the consumption of lactic acid bacteria (Barros et al., 2020). However, the term probiotic was first used by Lilly \& Stillwel, in 1965, originating from the Greek words pro and bios, which mean "for life" (Gismondo et al., 1999), and that refer to the opposite of "antibiotics, which means "against life" (Khaneghah et al., 2020).

Probiotics are live microorganisms that, when administered in appropriate doses, confer a health benefit to the host (Hill et al., 2014). A recent definition by the National Institutes of Health (NIH) of the United States Department of Health \& Human Services has attributed the term "probiotics", in the simplest form, as "live microorganisms that are intended to have health benefits when consumed or applied to the body" (National Institutes of Health, 2016). However, Zendeboodi et al. (2020) criticize the existing probiotics definitions, and thus, from a new approach, they define probiotics as "viable or non-viable microbial cell (vegetative or spore; intact or broken) that is potentially healthy for the host", presenting a new concept.
Although most probiotics added in foods are lactic acid bacteria (Kechagia et al., 2013; Lucatto et al., 2020; Ryan et al., 2020 ) with clinical effect to the health (Eor et al., 2020; Grom et al., 2020; Lee et al., 2020; Balthazar et al., 2021), recent investigations have presented several yeast species with probiotic properties (Arevalo-Villena et al., 2017; Greppi et al., 2017; Vohra et al., 2016). According to Fernandez-Pacheco et al. (2018), yeast strains with functional potential may be an alternative to produce probiotic medicines and foods. Although the probiotic effects of various yeast strains have been extensively demonstrated, the incorporation of these microorganisms in food matrices proves challenging (Amorim et al., 2018; Cagno et al., 2020; Greppi et al., 2017; Sarwar et al., 2019).

Yeasts are eukaryotic, unicellular microorganisms belonging to the kingdom Fungi, from which Saccharomyces is the main genus. Among them, Saccharomyces boulardii is a widely studied species used in many countries as a therapeutic and preventive agent (Kelesidis \& Pothoulakis, 2012; Hadjimbei et al., 2020) due to its probiotic properties, including its resistance to the acidic environment of the gastrointestinal tract, and improvements in the gut microbiota. S. boulardii was isolated from fruit in Indochina during a cholera outbreak, after scientist Henry Boulard noticed that people who drank tea from the outer skin of lychee and mangosteen did not get diarrhea. Consequently, $S$. boulardii began to be used to treat diarrhea as early as 1950 and currently this yeast is commercially available in several countries 
in South America, Europe, and Africa (Edwards-Ingram et al., 2007; McFarland, 2017).

In addition to the probiotic properties attributed to $S$. boulardii, recent prospects for a more integrated strategy suggest the potential use of this species in the development of functional food products (Capece et al., 2018; Senkarcinova et al., 2019; Sarwar et al., 2019), thus representing an important alternative and trend for its application in the food industry. In this context, the present study provides an overview of recent published data on the application of probiotic yeast in foods, with special focus on S. boulardii as a trend to develop innovative functional food products.

\section{Probiotics yeasts in food development}

The main probiotic microorganisms belong to the bacterial genera Lacticaseibacillus, Lactiplantibacillus and Bifidobacterium (Oliveira et al., 2021). Thus, most studies on the incorporation of probiotics in foods have drawn attention on different species from those genera (Arevalo-Villena et al., 2017; Cagno et al., 2020). However, several investigations have attributed yeast species as probiotic candidates, such as Kluyveromyces marxianus, $K$, lactis, Pichia kluyveri, P. pastoris, Candida famata, C. tropicalis and Saccharomyces boulardii (França et al., 2015; ArevaloVillena et al., 2017; Greppi et al., 2017). In addition, the isolation and characterization of new yeast strains with potential health benefits has been an attractive alternative for researchers, especially related to probiotic characteristics (Cassanego et al., 2018; Yildiran et al., 2019).

Among the probiotic properties attributed to yeasts, it should be mentioned the resistance to acidic environments, effects against enteric bacterial pathogens, anti-inflammatory action, stimulation and modulation of the immune system, improvement and restoration of the integrity of the intestinal epithelium, and improvement in nutrient bioavailability (Moslehi-Jenabian et al., 2010; Thévenot et al., 2015; Sen \& Mansell, 2020).

Table 1 shown the outcomes from recent studies on the use of probiotics yeasts in food matrices. Greppi et al. (2017) studied the probiotic potential of Pichia kudriavzevii and its ability to increase folate content (also known as vitamin $\mathrm{B}_{9}$ ), which plays a fundamental role in cell metabolism, in fermented foods. The authors found that this yeast was able to survive the conditions of the gastrointestinal tract as well as to adhere to intestinal cells and produce folate and phytase, thus concluding that $P$. kudriavzevii can increase the nutritional quality of food via fermentation and provide beneficial effects on the human host. Banik et al. (2019) isolated a strain of S. cerevisiae AKP1 from fermented foods and demonstrated that the anti-inflammatory activity of this species by modulating the cytokine profile of the immune system. In addition, they showed the potential for treating cold-induced gastric ulcers in in vivo trials using rat models. Helmy et al. (2019), evaluating the potentially probiotic attributes of milk yeasts isolated from Karish cheese, found that the yeasts P. kudriavzevii QLB, Wickerhamomyces anomalus HN1 and S. cerevisiae gbLKX237673.1 exhibited advantageous probiotic attributes in vitro, as well as high tolerance to bile salts at levels of up to $2.0 \%$.

In a recent review, Sen \& Mansell (2020) described the important role of yeasts as probiotics, their mechanisms, and potential use. The authors highlighted that, although several studies have shown beneficial and probiotic effects of yeast strains, there are still challenges for the incorporation of these microorganisms in real food products with the purpose of adding functional properties.

\section{Saccharomyces boulardii as a probiotic yeast}

S. boulardii, also known as S. cerevisiae var. boulardii or $S$. cerevisiae Hansen CBS 5926, is the most common yeast with alleged probiotic effects. This species was isolated from the peel of lychee and mangosteen fruits in 1920 by French scientist Henri Boulard (McFarland, 2010). Since then, S. boulardii has been commercialized in its lyophilized form worldwide as an effective product for treatment of diarrhea and prevention of complications related to the use of antibiotics (Buts, 2009). These allegations have stimulated the scientific interest on the probiotic effects of $S$. boulardii on the host's organism since the 1980's (Ducluzeau \& Bensaada, 1982; Buts, 2009). However, reports in the literature on the application of this yeast in food started only recently (Lourens-Hattingh \& Viljoen, 2001; Rekha

Table 1. Probiotic yeasts in food processing and development.

\begin{tabular}{|c|c|c|}
\hline Type of process or food & Probiotic yeast lineage & Reference \\
\hline Cereal-based fermented foods & Pichia kudriavzevii & Greppi et al. (2017) \\
\hline Fermentation of table and black olives & $\begin{array}{l}\text { Candida norvegica, Galactomyces reessii } 34 \mathrm{~A} \text { and } \\
\text { Pichia guilliermondii, Aureobasidium pullulans } \mathrm{Y} 42 \text {, } \\
\text { Saccharomyces cerevisiae } \mathrm{Y} 34\end{array}$ & $\begin{array}{l}\text { Oliveira et al. (2017) } \\
\text { Bonatsou et al. (2018) }\end{array}$ \\
\hline Pineapple fermented beverages & Meyerozyma caribbica & Amorim et al. (2018) \\
\hline Production of craft beers & Saccharomyces boulardii & $\begin{array}{l}\text { Capece et al. (2018) } \\
\text { Mulero-Cerezo et al. (2019) }\end{array}$ \\
\hline Traditional Egyptian cheese (Karish type) & $\begin{array}{l}\text { Pichia kudriavzevii QLB, Wickerhamomyces anomalus } \\
\text { HN1 and Saccharomyves cerevisiae gbLKX237673.1 }\end{array}$ & Helmy et al. (2019) \\
\hline Alcoholic fermented beverages & S. boulardii & Paula et al. (2019) \\
\hline Cornelian cherry functional beverage (Cornus mas L.) & $\begin{array}{l}\text { P. kudriavzevii DCNa1 and Wickerhamomyces } \\
\text { subpelliculosus DFNb6 }\end{array}$ & Cagno et al. (2020) \\
\hline Dairy products & $\begin{array}{l}\text { S. boulardii, Kluyveromyces marxianus and } P \text {. } \\
\text { kudriavzevii }\end{array}$ & $\begin{array}{l}\text { Sarwar et al. (2019) } \\
\text { Saadat et al. (2020) }\end{array}$ \\
\hline
\end{tabular}


\& Vijayalakshmi, 2008; Parrella et al., 2012; Rajendran et al., 2017; Capece et al., 2018; Swieca et al., 2019).

S. boulardii is a mesophilic and non-pathogenic yeast, also being metabolically and physiologically different from $S$. cerevisiae because of its resistance to low $\mathrm{pH}$, ideal growth temperature at $37{ }^{\circ} \mathrm{C}$ and tolerance to bile acids, among other characteristics (McFarland, 2017). According to Edwards-Ingram et al. (2007), this probiotic yeast can grow in $\mathrm{pH}$ between 2.0 and 7.0, and due to its ability to survive in acidic environments, it can pass unaltered throughout the digestive system (Edwards-Ingram et al., 2007). Figure 1 presents the main biochemical, physiological, and genetic characteristics that enable this yeast as a desirable biotherapeutic agent for humans.

S. boulardii has several additional attributes that provide probiotic properties, such as the beneficial effects against enteric pathogens, including the production of compounds that neutralize microbial toxins, prevention of bacterial adherence and translocation in intestinal epithelial cells and modulation of the host cell signaling pathway associated with the pro-inflammatory response in bacterial infection (Moslehi-Jenabian et al., 2010). According to the literature, studies have attributed positive effects to $S$. boulardii in the treatment of inflammatory bowel disease (Abbas et al., 2014) and acute gastrointestinal diseases, such as viral and bacterial diarrhea (Kelesidis \& Pothoulakis, 2012). $\mathrm{Xu}$ et al. (2016) evaluated the administration of $S$. boulardii in premature newborns to improve tolerance to growth and feeding and observed that the prophylactic use of $S$. boulardii in premature newborns accelerates weight gain and improves feeding tolerance. Additionally, in vivo experiments conducted with mice demonstrated the effectiveness of the oral administration of $S$. boulardii in the modulation of infection pathways in the intestinal mucosa, thus suggesting a new and valuable therapeutic strategy for intestinal inflammation (Justino et al., 2020).

\section{Saccharomyces boulardii applications in functional foods}

According to recent definitions (Rai et al., 2019), functional foods are conventional food products that bring health benefits in addition to their nutritional properties when administered and/or eaten as part of the normal diet. Ali \& Rahut (2019) highlighted the rising demand for functional foods, which is motivated by health care awareness and increased life expectancy. In this context, Kozup et al. (2003) pointed out that consumers may have favorable attitudes that consolidate their willingness to purchase functional foods, when these products are displayed as healthy and have advantageous nutritional factors.

The application of yeasts in the food industry has a long history with several examples, including the production of specific enzymes and new bioactive peptides and the use of living cells with probiotic properties and constituents of cell wall (example for $\beta$-glucans) with nutraceutical function (Padilla et al., 2015; Rai et al., 2016; Rai et al., 2019). Recent studies have attempted to include probiotic yeasts in the production of functional foods (Amorim et al., 2018; Capece et al., 2018; Cagno et al., 2020). Considering the probiotic properties attributed especially to S. boulardii, several studies have focused on the potential inclusion of this yeast in the development of innovative functional food products. The application of $S$. boulardii in food production was initially reported in the incorporation and preparation of commercial yogurts (Lourens-Hattingh \& Viljoen, 2001) and in the fermentation of vegetable products (Sindhu \& Khetarpaul, 2002). However, there is no available information on the effect of S. boulardii on organoleptic properties of foods; thus, sensory

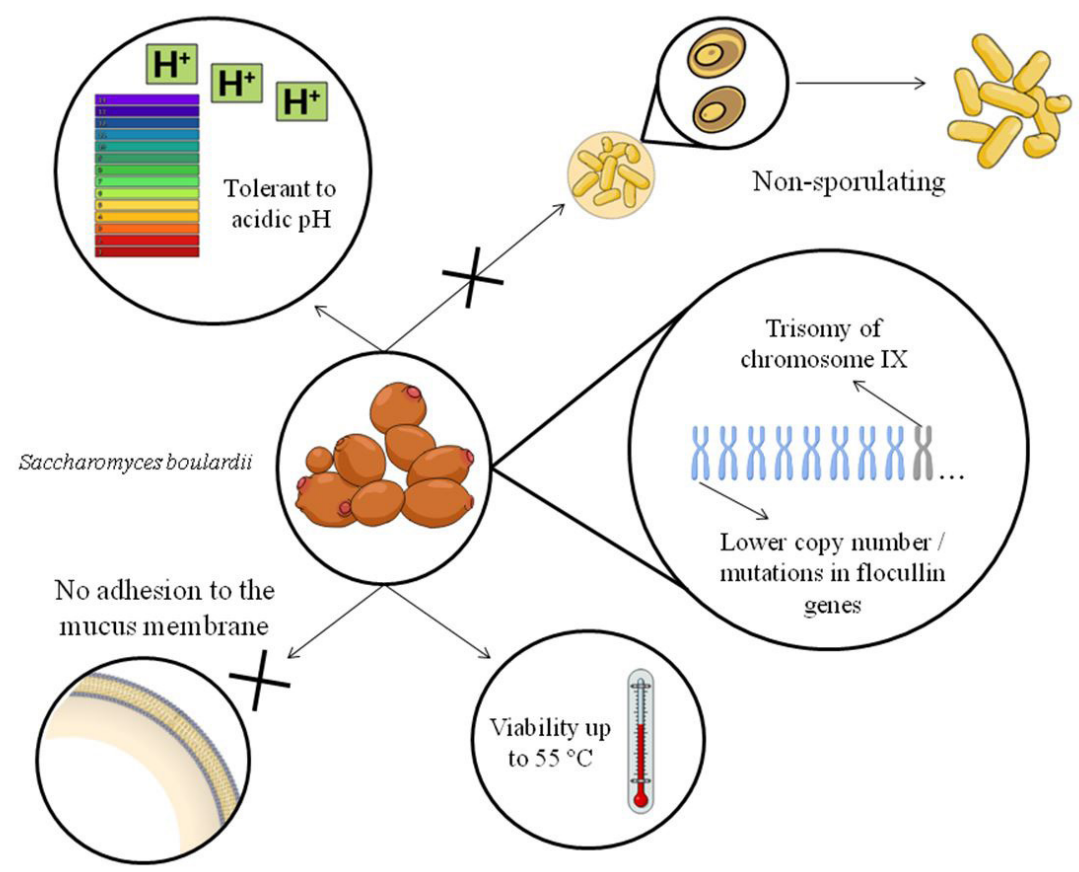

Figure 1. Main characteristics of Saccharomyces boulardii that can favor and assist its probiotic function (adapted from Sen \& Mansell, 2020). 
studies should be performed with this probiotic strain (Costa et al., 2020; Cruz et al., 2021; Silva et al., 2021).

\subsection{Non-alcoholic beverages}

The incorporation of $S$. boulardii as a probiotic yeast strain in the development of non-alcoholic beverages was firstly carried out by Lourens-Hattingh \& Viljoen (2001), who reported the growth capacity of $S$. boulardii in yogurt produced with Lactobacillus acidophilus and Bifidobacteria. The authors showed that $S$. boulardii can use the constituents of yogurt as a growth substrate to maintain cell viability, suggesting that this yeast species has a potential for use as a probiotic microorganism in dairy products, since no gas or alcohol formation was observed. Accordingly, Parrella et al. (2012) studied the co-fermentation of lactic acid bacteria in association with the probiotic yeast $S$. boulardii in the development of fermented milks. In their experiments, the authors found that yeast can use the fermentation products of lactic acid bacteria, such as organic acids, for their growth and to guarantee the stability of bacterial strains, as well as to improve the antioxidant properties of the final fermented product. Sarwar et al. (2019) studying the application of S. boulardii CNCM I-745 and prebiotic inulin in yogurt, developed a symbiotic product that was an effective vehicle for this probiotic yeast, which emphasizes its potential application as a new functional dairy product with beneficial properties for the health.

Pachori \& Kulkarni (2017) investigated the use of S. boulardii in the development of non-alcoholic probiotic coconut water and demonstrated that the consumption of this product was more beneficial than its regular counterpart (non-probiotic). In addition, the probiotic inclusion process does not change the color, flavor and palatability of the final product. In this way, the authors recommend that probiotic coconut water can serve as a drink alternative for vegetarian and allergic consumers of probiotic dairy products.

Regarding non-dairy beverages, Senkarcinova et al. (2019) studied the use of $S$. boulardii in the development of alcoholfree probiotic beer, showing that the yeast was able to ferment the beer wort and improve some variables of the fermentative process, leading to a better production of volatile compounds. Thus, such a study proposes that probiotic yeasts linked to nonalcoholic beers may link additional health benefits and become an attractive alternative for new beer products. Santana et al. (2020) studied the feasibility of applying S. boulardii in cashew juice from the Brazilian "cerrado" with the addition of fructose, sucrose and xylitol, and the artificial sweeteners aspartame, stevia and sucralose. They added $10^{8}$ colony forming units (CFU) $\mathrm{mL}^{-1}$ of $S$. boulardii to the juice samples and, after 28 days of storage, the cell viability of this species was greater than $7 \log \mathrm{CFU} \mathrm{mL} \mathrm{L}^{-1}$ for most samples evaluated, allowing the juice to be considered as a probiotic beverage.

\subsection{Vegetal products and bakery}

In vegetable and bakery products, experimental data from recent years have shown that the use of $S$. boulardii in combination with other microorganisms is a promising alternative for the development of new products (Rekha \& Vijayalakshmi, 2008;
Rajendran et al., 2017; Swieca et al., 2019). Rekha \& Vijayalakshmi (2008) analyzed the combination of S. boulardii with isolates of probiotic lactic acid bacteria in the fermentation of water-soluble soy extract, showing that the association of these microorganisms reduced antinutrients such as phytic acid, polyphenols and trypsin inhibitor.

In a study on the ability of $S$. boulardii SAA655 and Lactococcus lactis N8 to synthesize B complex vitamins (riboflavin and folate), Rajendran et al. (2017) found that the incorporation of these microorganisms improved the functional and technological characteristics of the Idli dough, a traditional cake based on vegetables and legumes widely consumed in the Indian subcontinent. Swieca et al. (2019) evaluated lentil sprouts and adzuki beans as carriers of $S$. boulardii and found that the probiotic yeast significantly improved the microbiological quality of the final products. Based on these results, the authors introduced the legume sprouts enriched with $S$. boulardii as a new functional food product, characterized by safety and high nutritional properties.

S. boulardii species was also recently isolated from fresh soybean paste and subjected to in vitro conditions for simulating the digestion process in the mouth, stomach and small intestine (Hossain et al., 2020). According to physical-chemical analyzes performed, the species was able to survive to stomach conditions, as well as at $2 \%$ bile salt and at $\mathrm{pH} 2.5$, also showing resistance to antibiotics such as imipenem, ampicillin and amikacin. Furthermore, the yeast presented bacteriostatic action for most of the gram-negative and gram-positive pathogenic bacteria tested, such as Salmonella typhi and Enterococcus faecalis, respectively.

S. boulardii has also been applied to corn flakes used as a breakfast cereal, usually consumed with hot milk (Singu et al., 2020). To protect the probiotic cells from hot temperatures and keep them viable in the consumed product, hydrocolloids were used as a coating agent mixed with $S$. boulardii. Among the tested hydrocolloids, gum Arabic proved to be the most protective coating material for cells after mixture with preheated milk at $80^{\circ} \mathrm{C}$. In addition, the survival rate of $S$. boulardii was $88 \%$ in corn flakes coated with probiotics stored for 90 days at $30^{\circ} \mathrm{C}$.

\subsection{Alcoholic fermented beverages}

The applicability of $S$. boulardii in co-fermentation with $S$. cerevisiae to produce craft beers was studied by Capece et al. (2018), who demonstrated that probiotic yeast has the capacity to survive during the brewing process. The probiotic yeast also increased the antioxidant properties of beer and showed high dominance at the end of co-fermentation with different strains of $S$. cerevisiae, thus confirming its potential for improving the quality of beer with low alcohol content or without alcohol. Accordingly, Mulero-Cerezo et al. (2019) also proposed the use of $S$. boulardii as a valuable probiotic initiator in the production of craft beer, providing greater antioxidant activity, lower alcohol level, similar sensory attributes, and greater cell viability after 45 days when compared to a S. cerevisiae strain commonly used in the beer industry.

Paula et al. (2019) applied the response surface analysis methodology to optimize the growth parameters of $S$. boulardii in 
synthetic must, and its tolerance under conditions that reproduce gastrointestinal transit in humans, aiming at the development of probiotic alcoholic beverages. The authors concluded that $S$. boulardii offers a new avenue for the management for production of alcoholic beverages with perspectives to markedly improve the quality of these products.

\section{Conclusions}

Among the microorganisms that provide benefits to the host, several strains and lineages of yeasts have been recognized as excellent alternatives with probiotic functions. Considering the beneficial effects attributed to probiotic yeasts, there is an increased scientific interest on the incorporation of these microorganisms in foods with functional characteristics. S. boulardii is one of the main probiotic yeasts species with beneficial health effects that has been studied regarding its potential for using in the development of innovative functional foods. Recent investigations indicate the potential application of $S$. boulardii in fermented vegetable products, bakery products, non-alcoholic and alcoholic beverages, especially in craft beers, which production market that has significantly expanded in recent years.

\section{Acknowledgements}

This study was financed in part by the Coordenação de Aperfeiçoamento de Pessoal de Nível Superior - Brasil (CAPES) - Finance Code 001.

\section{References}

Abbas, Z., Yakoob, J., Jafri, W., Ahmad, Z., Azam, Z., Usman, M. W., Shamim, S., \& Islam, M. (2014). Cytokine and clinical response to Saccharomyces boulardii therapy in diarrhea-dominant irritable bowel syndrome: a randomized trial. European Journal of Gastroenterology \& Hepatology, 26(6), 630-639. http://dx.doi. org/10.1097/MEG.0000000000000094. PMid:24722560.

Ali, A., \& Rahut, D. B. (2019). Healthy foods as proxy for functional foods: consumers' awareness, perception, and demand for natural functional foods in Pakistan. International Journal of Food Sciences, 2019, 6390650. http://dx.doi.org/10.1155/2019/6390650. PMid:31187040.

Amorim, J. C., Piccoli, R. H., \& Duarte, W. F. (2018). Probiotic potential of yeasts isolated from pineapple and their use in the elaboration of potentially functional fermented beverages. Food Research International, 107, 518-527. http://dx.doi.org/10.1016/j. foodres.2018.02.054. PMid:29580515.

Arevalo-Villena, M., Briones-Perez, A., Corbo, M. R., Sinigaglia, M., \& Bevilacqua, A. (2017). Biotechnological application of yeasts in food science: Starter cultures, probiotics and enzyme production. Journal of Applied Microbiology, 123(6), 1360-1372. http://dx.doi. org/10.1111/jam.13548. PMid:28744990.

Balthazar, C. F., Moura, N. A., Romualdo, G. R., Rocha, R. S., Pimentel, T. C., Esmerino, E. A., Freitas, M. Q., Santillo, A., Silva, M. C., Barbisan, L. F., Cruz, A. G., \& Albenzio, M. (2021). Symbiotic sheep milk ice cream reduces chemically induced mouse colon carcinogenesis. Journal of Dairy Science, 104(7), 7406-7414. http:// dx.doi.org/10.3168/jds.2020-19979. PMid:33934866.

Banik, A., Mondal, J., Rakshit, S., Ghosh, K., Sha, S. P., Halder, S. K., Ghosh, C., \& Mondal, K. C. (2019). Amelioration of cold-induced gastric injury by a yeast probiotic isolated from traditional fermented foods. Journal of Functional Foods, 59, 164-173. http://dx.doi. org/10.1016/j.jff.2019.05.039.

Barros, C. P., Guimarães, J. T., Esmerino, E. A., Duarte, M. C. K. H., Silva, M. C., Silva, R., Ferreira, B. M., Sant’Ana, A. S., Freitas, M. Q., \& Cruz, A. G. (2020). Paraprobiotics and postbiotics: concepts and potential applications in dairy products. Current Opinion in Food Science, 32, 1-8. http://dx.doi.org/10.1016/j.cofs.2019.12.003.

Bonatsou, S., Karamouza, M., Zoumpopoulou, G., Mavrogonatou, E., Kletsas, D., Papadimitriou, K., Tsakalidou, E., Nychas, G. J. E., \& Panagou, E. Z. (2018). Evaluating the probiotic potential and technological characteristics of yeasts implicated in cv. Kalamata natural black olive fermentation. International Journal of Food Microbiology, 271, 48-59. http://dx.doi.org/10.1016/j.ijfoodmicro.2018.02.018. PMid:29494892.

Buts, J. P. (2009). Twenty-five years of research on Saccharomyces boulardii trophic effects: updates and perspectives. Digestive Diseases and Sciences, 54(1), 15-18. http://dx.doi.org/10.1007/s10620-0080322-y. PMid:18528758.

Cagno, R., Filannino, P., Cantatore, V., Polo, A., Celano, G., Martinovic, A., Cavoski, I., \& Gobbetti, M. (2020). Design of potential probiotic yeast starters tailored for making a cornelian cherry (Cornus mas L.) functional beverage. International Journal of Food Microbiology, 323, 108591. http://dx.doi.org/10.1016/j.ijfoodmicro.2020.108591. PMid:32222654.

Capece, A., Romaniello, R., Pietrafesa, A., Siesto, G., Pietrafesa, R., Zambuto, M., \& Romano, P. (2018). Use of Saccharomyces cerevisiae var. boulardii in co-fermentations with S. cerevisiae for the production of craft beers with potential healthy value-added. International Journal of Food Microbiology, 284, 22-30. http://dx.doi.org/10.1016/j. ijfoodmicro.2018.06.028. PMid:29990636.

Cassanego, D., Richards, N., Valente, P., Mazutti, M., \& RamírezCastrillon, M. (2018). Identification by PCR and evaluation of probiotic potential in yeast strains found in kefir samples in the city of Santa Maria, RS, Brazil. Food Science and Technology, 38(Suppl. 1), 59-65. http://dx.doi.org/10.1590/1678-457x.13617.

Costa, G. M., Paula, M. M., Costa, G. N., Esmerino, E. A., Silva, R., Freitas, M. Q., Barão, C. E., Cruz, A. G., \& Pimentel, T. C. (2020). Preferred attribute elicitation methodology compared to conventional descriptive analysis: a study using probiotic yogurt sweetened with xylitol and added with prebiotic components. Journal of Sensory Studies, 35(6), e12602. http://dx.doi.org/10.1111/joss.12602.

Cruz, M. F., Rocha, R. S., Silva, R., Freitas, M. Q., Pimentel, T. C., Esmerino, E. A., Cruz, A. G., Fidalgo, T. K. S., \& Maia, L. C. (2021). Probiotic fermented milks: children's emotional responses using a product-specific emoji list. Food Research International, 143, 110269. http://dx.doi.org/10.1016/j.foodres.2021.110269. PMid:33992370.

Ducluzeau, R., \& Bensaada, M. (1982). Comparative effect of a single or continuous administration of "Saccharomyces boulardii" on the establishment of various strains of "candida" in the digestive tract of gnotobiotic mice. Annales de Microbiologie, 133(3), 491-501. PMid:6762128.

Edwards-Ingram, L., Gitsham, P., Burton, N., Warhurst, G., Clarke, I., Hoyle, D., Oliver, S. G., \& Stateva, L. (2007). Genotypic and physiological characterization of Saccharomyces boulardii, the probiotic strain of Saccharomyces cerevisiae. Applied and Environmental Microbiology, 73(8), 2458-2467. http://dx.doi.org/10.1128/AEM.02201-06. PMid:17293506.

Eor, J. Y., Tan, P. L., Son, Y. J., Lee, C. S., \& Kim, S. H. (2020). Milk products fermented by Lactobacillus strains modulate the gut-bone axis in an ovariectomised murine model. International Journal of 
Dairy Technology, 73(4), 743-756. http://dx.doi.org/10.1111/14710307.12708 .

Fernandez-Pacheco, P., Arévalo-Villena, M., Bevilacqua, A., Corbo, M. R., \& Pérez, A. B. (2018). Probiotic characteristics in Saccharomyces cerevisiae strains: properties for application in food industries. Lebensmittel-Wissenschaft + Technologie, 97, 332-340. http://dx.doi. org/10.1016/j.lwt.2018.07.007.

França, R. C., Conceição, F. R., Mendonça, M., Haubert, L., Sabadin, G., Oliveira, P. D., Amaral, M. G., Silva, W. P., \& Moreira, N. A. (2015). Pichia pastoris X-33 has probiotic properties with remarkable antibacterial activity against Salmonella Typhimurium. Applied Microbiology and Biotechnology, 99(19), 7953-7961. http://dx.doi. org/10.1007/s00253-015-6696-9. PMid:26088173.

Gismondo, M. R., Drago, L., \& Lombardi, A. (1999). Review of probiotics available to modify gastrointestinal flora. International Journal of Antimicrobial Agents, 12(4), 287-292. http://dx.doi.org/10.1016/ S0924-8579(99)00050-3. PMid:10493604.

Greppi, A., Saubade, F., Botta, C., Humblot, C., Guyot, J. P., \& Cocolin, L. (2017). Potential probiotic Pichia kudriavzevii strains and their ability to enhance folate content of traditional cereal-based African fermented food. Food Microbiology, 62, 169-177. http://dx.doi. org/10.1016/j.fm.2016.09.016. PMid:27889145.

Grom, L. C., Rocha, R. S., Balthazar, C. F., Guimarães, J. T., Coutinho, N. M., Barros, C. P., Pimentel, T. C., Venâncio, E. L., Collopy, I. Jr., Maciel, P. M. C., Silva, P. H. F., Granato, D., Freitas, M. Q., Esmerino, E. A., Silva, M. C., \& Cruz, A. G. (2020). Postprandial glycemia in healthy subjects: which probiotic dairy food is more adequate? Journal of Dairy Science, 103(2), 1110-1119. http://dx.doi. org/10.3168/jds.2019-17401. PMid:31785881.

Hadjimbei, E., Botsaris, G., Goulas, V., Alexandri, E., Gekas, V., \& Gerothanassis, I. P. (2020). Functional stability of goats' milk yoghurt supplemented with Pistacia atlantica resin extracts and Saccharomyces boulardii. International Journal of Dairy Technology, 73(1), 134-143. http://dx.doi.org/10.1111/1471-0307.12629.

Helmy, E. A., Soliman, S. A., Abdel-Ghany, T. M., \& Ganash, M. (2019). Evaluation of potentially probiotic attributes of certain dairy yeast isolated from buffalo sweetened Karish cheese. Heliyon, 5(5), e01649. http://dx.doi.org/10.1016/j.heliyon.2019.e01649. PMid:31193166.

Hill, C., Guarner, F., Reid, G., Gibson, G. R., Merenstein, D. J., Pot, B., Morelli, L., Canani, R. B., Flint, H. J., Salminen, S., Calder, P. C., \& Sanders, M. E. (2014). The International Scientific Association for Probiotics and Prebiotics consensus statement on the scope and appropriate use of the term probiotic. Nature Reviews. Gastroenterology \& Hepatology, 11(8), 506-514. http://dx.doi. org/10.1038/nrgastro.2014.66. PMid:24912386.

Hossain, M. N., Afrin, S., Humayun, S., Ahmed, M. M., \& Saha, B. K. (2020). Identification and growth characterization of a novel strain of Saccharomyces boulardii isolated from soya paste. Frontiers in Nutrition, 7(27), 27. http://dx.doi.org/10.3389/fnut.2020.00027. PMid:32309286.

Justino, P. F. C., Franco, A. X., Pontier-Bres, R., Monteiro, C. E. S., Barbosa, A. L. R., Souza, M. H. L. P., Czerucka, D., \& Soares, P. M. G. (2020). Modulation of 5-fluorouracil activation of toll-like/ MyD88/NF- $\kappa$ B/MAPK pathway by Saccharomyces boulardii CNCM I-745 probiotic. Cytokine, 125, 154791. http://dx.doi.org/10.1016/j. cyto.2019.154791. PMid:31401369.

Kechagia, M., Basoulis, D., Konstantopoulou, S., Dimitriadi, D., Gyftopoulou, K., Skarmoutsou, N., \& Fakiri, E. M. (2013). Health benefits of probiotics: a review. ISRN Nutrition, 2013, 481651. http:// dx.doi.org/10.5402/2013/481651. PMid:24959545.
Kelesidis, T., \& Pothoulakis, C. (2012). Efficacy and safety of the probiotic Saccharomyces boulardii for the prevention and therapy of gastrointestinal disorders. Therapeutic Advances in Gastroenterology, 5(2), 111-125. http://dx.doi.org/10.1177/1756283X11428502. PMid:22423260.

Khaneghah, A. M., Abhari, K., Es, I., Soares, M. B., Oliveira, R. B. A., Hosseini, H., Rezaei, M., Balthazar, C. F., Silva, R., Cruz, A. G., Ranadheera, C. S., \& Sant'Ana, A. S. (2020). Interactions between probiotics and pathogenic microorganisms in hosts and foods: a review. Trends in Food Science \& Technology, 95, 205-218. http:// dx.doi.org/10.1016/j.tifs.2019.11.022.

Kozup, J. C., Creyer, E. H., \& Burton, S. (2003). Making healthful food choices: the infuence of health claims and nutrition information on consumers evaluations of packaged food products and restaurant menu items. Journal of Marketing, 67(2), 19-34. http://dx.doi. org/10.1509/jmkg.67.2.19.18608.

Lee, C. S., Lee, S. H., \& Kim, S. H. (2020). Bone-protective effects of Lactobacillus plantarum B719-fermented milk product. International Journal of Dairy Technology, 73(4), 706-717. http://dx.doi. org/10.1111/1471-0307.12701.

Lourens-Hattingh, A., \& Viljoen, B. C. (2001). Growth and survival of a probiotic yeast in dairy products. Food Research International, 34(9), 791-796. http://dx.doi.org/10.1016/S0963-9969(01)00085-0.

Lucatto, J. N., Silva-Buzanello, R. A., Mendonça, S. N. T. G., Lazarotto, T. C., Sanchez, J. L., Bona, E., \& Drunkler, D. A. (2020). Performance of different microbial cultures in potentially probiotic and prebiotic yoghurts from cow and goat milks. International Journal of Dairy Technology, 73(1), 144-156. http://dx.doi.org/10.1111/1471-0307.12655.

McFarland, L. V. (2010). Systematic review and meta-analysis of Saccharomyces boulardii in adult patients. World Journal of Gastroenterology, 16(18), 2202-2222. http://dx.doi.org/10.3748/ wjg.v16.i18.2202. PMid:20458757.

McFarland, L. V. (2017). Common organisms and probiotics: Saccharomyces boulardii. Implications for human health, prebiotics, probiotics, and dysbiosis. In M. H. Floch, Y. Ringel \& W. Allan (Eds.), The microbiota in gastrointestinal pathophysiology (pp. 145-164). Amsterdam: Elsevier.

Metchnikoff, E. (1907). Lactic acid as inhibiting intestinal putrefaction. In: P. C. Mitchell (Ed.), The prolongation of life: optimistic studies (pp. 161-183). London: W. Heinemann.

Moslehi-Jenabian, S., Pedersen, L. L., \& Jespersen, L. (2010). Beneficial effects of probiotic and food borne yeasts on human health. Nutrients, 2(4), 449-473. http://dx.doi.org/10.3390/nu2040449. PMid:22254033.

Mulero-Cerezo, J., Briz-Redón, Á., \& Serrano-Aroca, Á. (2019). Saccharomyces cerevisiae var. boulardii: valuable probiotic starter for craft beer production. Applied Sciences, 9(16), 3250. http://dx.doi. org/10.3390/app9163250.

National Institutes of Health - NIH. (2016). Probiotics: what you need to know. Retrieved from https://nccih.nih.gov/health/probiotics/ introduction.htm

Oliveira, C. A. F., Muaz, K., Møller, C. O. A., Corassin, C. H., \& Rattray, F. P. (2021). Probiotics and Mycotoxins. In: Cruz, A. G., Ranadheera, C. S., Nazzaro, F., Mortazavian, A. (Eds.), Probiotics and prebiotics in foods (pp. 309-328). London: Elsevier. http://dx.doi.org/10.1016/ B978-0-12-819662-5.00005-7

Oliveira, T., Ramalhosa, E., Nunes, L., Pereira, J. A., Colla, E., \& Pereira, E. L. (2017). Probiotic potential of indigenous yeasts isolated during the fermentation of table olives from Northeast of Portugal. Innovative Food Science \& Emerging Technologies, 44, 167-172. http://dx.doi. org/10.1016/j.ifset.2017.06.003. 
Pachori, R. R., \& Kulkarni, N. S. (2017). Studies on development of probioticated coconut water. Online International Interdisciplinary Research Journal, 7(spe), 9-17.

Padilla, B., Frau, F., Ruiz-Matute, A. I., Montilla, A., Belloch, C., Manzanares, P., \& Corzo, N. (2015). Production of lactulose oligosaccharides by isomerisation of transgalactosylated cheese whey permeate obtained by $\beta$-galactosidases from dairy Kluyveromyces. The Journal of Dairy Research, 82(3), 356-364. http://dx.doi.org/10.1017/ S0022029915000217. PMid:26004434.

Parrella, A., Caterino, E., Cangiano, M., Criscuolo, E., Russo, C., Lavorgna, M., \& Isidori, M. (2012). Antioxidant properties of different milk fermented with lactic acid bacteria and yeast. International Journal of Food Science \& Technology, 47(12), 2493-2502. http://dx.doi. org/10.1111/j.1365-2621.2012.03127.x.

Paula, B. P., Chávez, D. W. H., Lemos, W. J. F. Jr., Guerra, A. F., Corrêa, M. F. D., Pereira, K. S., \& Coelho, M. A. Z. (2019). Growth parameters and survivability of Saccharomyces boulardii for probiotic alcoholic beverages development. Frontiers in Microbiology, 10, 2092. http:// dx.doi.org/10.3389/fmicb.2019.02092. PMid:31552002.

Rai, A. K., Kumari, R., Sanjukta, S., \& Sahoo, D. (2016). Production of bioactive protein hydrolysate using the yeasts isolated from soft chhurpi. Bioresource Technology, 219, 239-245. http://dx.doi. org/10.1016/j.biortech.2016.07.129. PMid:27494105.

Rai, A. K., Pandey, A., \& Sahoo, D. (2019). Biotechnological potential of yeasts in functional food industry. Trends in Food Science \& Technology, 83, 129-137. http://dx.doi.org/10.1016/j.tifs.2018.11.016.

Rajendran, S. C., Chamlagain, B., Kariluoto, S., Piironen, V., \& Saris, P. E. J. (2017). Biofortification of riboflavin and folate in idli batter, based on fermented cereal and pulse, by Lactococcus lactis N8 and Saccharomyces boulardii SAA655. Journal of Applied Microbiology, 122(6), 1663-1671. http://dx.doi.org/10.1111/jam.13453. PMid:28339160.

Rekha, C. R., \& Vijayalakshmi, G. (2008). Biomolecules and nutritional quality of soymilk fermented with probiotic yeast and bacteria. Applied Biochemistry and Biotechnology, 151(2-3), 452-463. http:// dx.doi.org/10.1007/s12010-008-8213-4. PMid:18607548.

Ryan, J., Hutchings, S. C., Fang, Z., Bandara, N., Gamlath, S., Ajlouni, S., \& Ranadheera, C. S. (2020). Microbial, physico-chemical and sensory characteristics of mango juice-enriched probiotic dairy drinks. International Journal of Dairy Technology, 73(1), 182-190. http://dx.doi.org/10.1111/1471-0307.12630.

Saadat, Y. R., Khosroushahi, A. Y., Movassaghpour, A., Talebi, M., \& Gargari, B. P. (2020). Modulatory role of exopolysaccharides of Kluyveromyces marxianus and Pichia kudriavzevii as probiotic yeasts from dairy products in human colon cancer cells. Journal of Functional Foods, 64, 103675. http://dx.doi.org/10.1016/j.jff.2019.103675.

Santana, R. V., Santos, D. C., Santana, A. C. A., Oliveira, J. G. Fo., Almeida, A. B., Lima, T. M., Silva, F. G., \& Egea, M. B. (2020). Quality parameters and sensorial profile of clarified "Cerrado" cashew juice supplemented with Sacharomyces boulardii and different sweeteners. Lebensmittel-Wissenschaft + Technologie, 128, 109319. http://dx.doi. org/10.1016/j.lwt.2020.109319.

Sarwar, A., Aziz, T., Al-Dalali, S., Zhao, X., Zhang, J., Din, J., Chen, C., Cao, Y., \& Yang, Z. (2019). Physicochemical and microbiological properties of synbiotic yogurt made with probiotic yeast Saccharomyces boulardii in combination with inulin. Foods, 8(10), 468. http://dx.doi. org/10.3390/foods8100468. PMid:31658700.

Sen, S., \& Mansell, T. J. (2020). Yeasts as probiotics: mechanisms, outcomes, and future potential. Fungal Genetics and Biology, 137, 103333. http://dx.doi.org/10.1016/j.fgb.2020.103333. PMid:31923554.

Senkarcinova, B., Dias, I. A. G., Nespor, J., \& Branyik, T. (2019). Probiotic alcohol-free beer made with Saccharomyces cerevisiae var. boulardii. Lebensmittel-Wissenschaft + Technologie, 100, 362-367. http://dx.doi. org/10.1016/j.lwt.2018.10.082.

Silva, J. M., Barão, C. E., Esmerino, E. A., Cruz, A. G., \& Pimentel, T. C. (2021). Prebiotic frozen dessert processed with water-soluble extract of rice byproduct: vegan and nonvegan consumers perception using preferred attribute elicitation methodology and acceptance. Journal of Food Science, 86(2), 523-530. http://dx.doi.org/10.1111/17503841.15566. PMid:33438322.

Sindhu, S. C., \& Khetarpaul, N. (2002). Effect of probiotic fermentation on antinutrients and in vitro protein and starch digestibilities of indigenously developed RWGT food mixture. Nutrition and Health, 16(3), 173-181. http://dx.doi.org/10.1177/026010600201600303. PMid:12418801.

Singu, B. D., Bhushette, P. R., \& Annapure, U. S. (2020). Thermotolerant Saccharomyces cerevisiae var. boulardii coated cornflakes as a potential probiotic vehicle. Food Bioscience, 36, 100668. http:// dx.doi.org/10.1016/j.fbio.2020.100668.

Swieca, M., Kordowska-Wiater, M., Pytka, M., Gawlik-Dziki, U., Seczyk, L., Zlotek, U., \& Kapusta, I. (2019). Nutritional and pro-health quality of lentil and adzuki bean sprouts enriched with probiotic yeast Saccharomyces cerevisiae var. boulardii. Lebensmittel-Wissenschaft + Technologie, 100, 220-226. http://dx.doi.org/10.1016/j.lwt.2018.10.081.

Thévenot, J., Cordonnier, C., Rougeron, A., Goff, O., Nguyen, H. T., Denis, S., Alric, M., Livrelli, V., \& Blanquet-Diot, S. (2015). Enterohemorrhagic Escherichia coli infection has donor-dependent effect on human gut microbiota and may be antagonized by probiotic yeast during interaction with Peyer's patches. Applied Microbiology and Biotechnology, 99(21), 9097-9110. http://dx.doi.org/10.1007/ s00253-015-6704-0. PMid:26084888.

Vohra, A., Syal, P., \& Madan, A. (2016). Probiotic yeasts in livestock sector. Animal Feed Science and Technology, 219, 31-47. http://dx.doi. org/10.1016/j.anifeedsci.2016.05.019.

World Health Organization - WHO. Probiotics in food: Health and nutritional properties and guidelines for evaluation. Rome: FAO/WHO; 2006.

Xu, L., Wang, Y., Wang, Y., Fu, J., Sun, M., Mao, Z., \& Vandenplas, Y. (2016). A double-blinded randomized trial on growth and feeding tolerance with Saccharomyces boulardii CNCM I-745 in formula-fed preterm infants. Jornal de Pediatria, 92(3), 296-301. http://dx.doi. org/10.1016/j.jped.2015.08.013. PMid:26946967.

Yildiran, H., Basyigit Kiliç, G., \& Çakmakçi, A. G. K. (2019). Characterization and comparison of yeasts from different sources for some probiotic properties and exopolysaccharide production. Food Science and Technology, 39(Suppl. 2), 646-653. http://dx.doi. org/10.1590/fst.29818.

Zendeboodi, F., Khorshidian, N., Mortazavian, A. M., \& Cruz, A. R. (2020). Probiotic: conceptualization from a new approach. Current Opinion in Food Science, 32, 103-123. http://dx.doi.org/10.1016/j. cofs.2020.03.009. 